\title{
Implementation of Maintenance and Repair of Workshop Tools on Machining Expertise Vocational High School in Yogyakarta Industry-Based
}

\author{
Ridho Aritonang*, Thomas Sukardi \\ Graduate School of Yogyakarta State University,Yogyakarta,Indonesia \\ *Corresponding author: ridhoaritonang.2017@student.uny.ac.id
}

Received August 17, 2019; Revised September 20, 2019; Accepted October 07, 2019

\begin{abstract}
This study aims to determine the quality of (1) planning, (2) actuating, and (3) controlling in the management of workshop tools in Vocational High Schools (VHSs) of machining expertise at Yogyakarta City. The study is quantitative research with the survey method. Respondents in this study are heads of departments, productive teachers, and technicians, while those in the industry are heads of workshops, technicians, and operators. Data collection techniques were used questionnaires, interviews, and observations. The data analysis technique used descriptive statistics. The results showed that: (1) planning in the Industry side has good quality with a mean of 3.18 while VHSs have good quality with a mean of 2.81; (2) actuating in the Industry has very good quality with a mean of 3.30 while at VHSs it has good quality with a mean of 2.68; and (3) controlling in the Industry as good quality with a mean of 3.13 while VHSs has good quality with a mean of 2.61.The research results imply that VHSs can find out to what extent management has been carried out and Industry can provide an overview and solutions to Vocational High Schools to be better.
\end{abstract}

Keywords: management, maintenance and repair, workshop of machining expertise practices

Cite This Article: Ridho Aritonang, and Thomas Sukardi, "Implementation of Maintenance and Repair of Workshop Tools on Machining Expertise Vocational High School in Yogyakarta Industry-Based." American Journal of Educational Research, vol. 7, no. 10 (2019): 670-676. doi: 10.12691/education-7-10-2.

\section{Introduction}

In the industrial world, the product is the main result of a production process that forms a production process system. The production process system consists of inputs, operating processes, and outputs. For a production process system to continue running, it requires maintenance activities for the production machine tools. Maintenance is an operational partner for efficiency, especially in industry, operational should recognize the benefits of working together with maintenance, as a supportive team to reduce unplanned breakdowns, to increase equipment effectiveness, and to reduce overall maintenance costs [1]. The concept of equipment maintenance is present and indispensable in any production. Industrial maintenance is needed for equipment because the efficiency and quality of production decreases over time and machines may fail more often. Implementation of maintenance management is an important problem in preventing losses due to damage in a company. This will be increasingly important when the production system increases and the quality of production increases [2]. Therefore, technical systems which are in regular condition for long periods of time that function regularly, need to be maintained properly [3]. Maintenance is a combination of all technical, administrative and managerial actions during the production cycle of a machine to store or restore it to a state in which it can perform the required function. Maintenance includes all efforts intended to keep assets (facilities, equipment, etc.) in acceptable working conditions [4].

The industrial production process consists of inputs, operational processes, and outputs. Vocational High Schools (VHSs) are educational institutions that have the potential to prepare human resources and emphasize the learning process in an effort to provide skills to students so that they have the ability to maintain their existence in life so that they can be easily absorbed by the world of work. As stated in Law No. 20 of 2003 in Indonesia, the Vocational School aims to prepare graduates to enter the workforce [5]. A good output is certainly a good strategy to give satisfaction to the customer. Reference [6] shows that customer satisfaction with maintenance performance has a relationship with the type of workshop maintenance strategy used by management. Therefore, the maintenance management system and its application are very important for the overall efficiency of facility equipment [7].

Reference [8] shows that the fundamental problem faced by VHSs, especially the current technology group is the achievement of minimum competency skills to master basic principles and manual skills for students. The reason for the achievement of mastery of student competency has not been achieved, among others, because VHSs are not 
professionally managed both regarding the management system, the learning process, and the completeness of the practical facilities and infrastructure. So that it will have a negative impact on graduates, both covering hard skills and soft skills. Based on the analysis of the National Accreditation Board for Schools/Madrasas (BAN S/M in Indonesia) there are three standards that have low performance, namely the standards of educators and education personnel, facilities and infrastructure standards, and management standards. Therefore, this is a problem that must be addressed immediately related to the National Medium-Term Development Plan (RPJMN in Indonesia) 2020-2024 [9].

Educational institutions, especially vocational high schools need adequate practice facilities, meaning that in their capacity and diversity must be met in accordance with the demands of achieving competencies that must be mastered by students. Reference [10] shows the standard facilities and infrastructure for Vocational High Schools to be achieved so that VHS is required to always be ready with the practice facilities to be used. one way to protect these assets is to carry out programmed and scheduled maintenance. The basic objectives of maintenance management and repair of workshop equipment are (1) machines or tools available in good condition; (2) readiness of backup equipment in an emergency; (3) human and environmental safety; (4) longer machine or chisel life [11]. The maintenance process serves to ensure the availability, reliability and security of assets. Therefore, it is necessary to choose the parts of equipment that are most suitable for use in maintenance activities [12].

The maintenance of machine facilities must be carried out in a planned manner to achieve optimal results and goals. In addition, officers who are provided with care responsibilities must be professional in their fields. Therefore, the problem of maintaining machine facilities requires not only knowledge in their field but also have a high attitude, responsibility, and discipline because this is closely related to the problem of readiness, safety, and comfort in using a tool or facility owned by a workshop. Reference [13] shows that there are several things that need to be considered in the implementation of maintenance and repair of machine tools, namely: (1) culture Implementation of routine maintenance, running maintenance; (2) carrying out routine machine inspections; (3) implementation of preventive maintenance which includes, periodic inspections, periodic inspection reports, periodic component replacement, periodic setting and testing.

Generally, in terms of implementation maintenance work is divided into two ways that are closer to reality in a company, namely: (1) planned maintenance; (2) unplanned maintenance [14]. Reference [15] shows that with preventive maintenance measures, maintenance costs can be saved at $8 \%$. In addition, management theory with practical applications leads to greater productivity and higher quality [16]. Knowledge management must be achieved through an integrated and comprehensive company strategy, including policy implementation, monitoring, and evaluation [17]. Therefore, the management of maintenance and repair of workshop equipment consists of planning, actuating and controlling.
Planning is the selection or determination of organizational goals and determining the strategies, policies, projects, programs, procedures, methods, systems, budgets, and standards needed to achieve goals. Organizational planning has objectives, namely: (1) the organization can obtain and bind the resources needed to achieve these goals; (2) members of the organization carry out activities that are consistent with selected objectives and procedures; (3) progress can be continuously monitored and measured, so that corrective action can be taken if the level of progress is not satisfactory [18]. In general, a good plan contains six elements, namely: The what, The way, The where, The when, The who and The how. Therefore, a good plan must provide answers to six questions, namely: (1) What actions must be taken? (2) What is the reason for this action? (3) Where should the action be carried out? (4) When was the action carried out? (5) Who will do the action? (6) How do you carry out the action? [19]. The planning element in the process of maintenance management and repair of workshop equipment consists of work procedures, detailed activities, reasons for implementing the activities, location of activities and facilities needed, time for implementation, staff, and costs for the implementation of maintenance and repairs. Actuating is the relationship between individual aspects caused by the relationship with subordinates to be able to understand the division of work that is effective and efficient. Actuating is a very important part of the management process [20]. Implementation is a decision that has been determined in the planning. Implementation as a second management function which is a process of how to implement the results of planning in a tangible manner in order to achieve the objectives of the activity optimally [21].

The actuating process in management includes: (1) Conducting participatory activities with pleasure in all decisions, actions or actions; (2) Directing others to work their best; (3) Motivating members; (4) Communicating effectively; (5) Increase members to fully understand their potential; (6) Reward rewards for workers who do good work; (7) Sufficient for employee needs in accordance with work activities; (8) Attempts to correct direction according to supervision instructions [22] actuating is an effort to influence all group members to want to achieve organizational goals and try to achieve common goals.

Controlling is one of the functions of management in the form of assessing and making corrections so that what is being done by subordinates can be directed to the right tasks and planning objectives can be achieved. In carrying out control activities, superiors carry out checks, compatibility, and efforts so that the activities carried out in accordance with the plans that have been set [12]. Controlling has several objectives, namely: (1) comparing the results of work with the overall plan; (2) assess work results with work standards; (3) making the implementation media appropriately; (4) notifying the media measuring the job; (5) moving data in detail so that it can be seen the comparison and irregularities; (6) making suggestions for corrective actions to members; (7) notifying members who are responsible for providing explanations; (8) carry out supervision in accordance with the results of the supervision [1]. 
References [23] explain that there are several types of controls including employee control (to find out whether employees work according to plans, work procedures, discipline, attendance, etc.); budget control; time control (according to plan or not); production control (production according to standards or plans); technician control; policy control; sales control; control inventory; maintenance companies that control and if there is any damage, what can be repaired or not. Therefore it can be concluded, control is the process by which managers ensure that the resources obtained can be used effectively, efficiently and guide employee behavior in the desired direction so that employee behavior and decisions can continue to be consistent with strategy and goals.

\section{Research Methodology}

This research is intended to examine the condition of maintenance management and repair of workshop equipment in the industry with the condition of maintenance management and repair of workshop equipment that is in the Vocational High Schools (VHSs) of machining expertise in Yogyakarta City. The design of this research is used quantitative descriptive to measure the quality of maintenance management and repair of workshop equipment at VHSs. The research data analysis technique is done by using descriptive statistics by calculating the mean (M) of each indicator. Mean is an explanation technique based on the average value of a group that can be calculated with the following formula:

$$
M e=\frac{\sum x^{i}}{n}
$$

Where Me $=$ mean, $\sum x^{i}=$ the number of values $\mathrm{X}$ to i up to $n, n=$ number of individuals [24].

This research was conducted in several stages, namely: conceptualization, data collection, data analysis, and final report. This research was conducted at VHSs in Yogyakarta in the field of machining expertise, namely: SMK Negeri 2 Yogyakarta, SMK Negeri 3 Yogyakarta, SMK Muhammadiyah 3 Yogyakarta, and SMK Piri 1 Yogyakarta. The subjects in this study were the head of engineering, departments, productive teachers, and technicians from each VHSs in Yogyakarta. The other sample which is portrait a maintenance management and repair of workshop equipment is PT. MAK with the subject of the workshop head, technicians and operators. The reason of the subject was chosen as a respondent in this study was that the subject carried out maintenance management and repair of workshop equipment so that the subject was directly involved in managing the maintenance and repair of the workshop.

The object of this study is a machining practice workshop, the sampling technique in this study is random sampling from all members of the population, whereas to determine the number of samples using the Taro Yamane or Sloving

$$
n=\frac{N}{N \cdot d^{2}+1}
$$

Where $n=$ sample size, $\mathrm{N}=$ the size of the population being the respondent, $d=$ precision value (set at $5 \%$ with a confidence level of 95\%) [25].

The following is a list used as respondents in the research, namely:

Table 1. List of Industry and VHSs in Machining Expertise Competencies and Number of Respondents in Machining Practices in Yogyakarta

\begin{tabular}{|c|c|c|c|}
\hline No & $\begin{array}{c}\text { Name of Vocational High } \\
\text { School (VHSs) }\end{array}$ & Status & Respondent \\
\hline 1 & SMKN 2 Yk. & State School & 15 \\
2 & SMKN 3 Yk. & State School & 20 \\
3 & SMK Muh 3 Yk & Private School & 13 \\
4 & SMK Piri 1 Yk & Private School & 4 \\
5 & PT. MAK & Private School & 6 \\
\hline \multicolumn{2}{|c|}{ Total } & 58 \\
\hline
\end{tabular}

Based on formula (2) with a population of 58 respondents, the number of samples obtained in this study was 50 respondents.

Data collection techniques in this study using a questionnaire as the main data source that will be supported by observation and interview data. The questionnaire is used in research to get data or information made in the form of questions. The questionnaire in this study was made in the form of closed questions, meaning the questions given were given alternative answers that have been set so that respondents only need to choose the column that has been provided and later the results of the questionnaire will get objective data. Observation activity aims to see the completeness of machine maintenance equipment and supporting areas for the implementation of maintenance and repair of workshop equipment. Therefore, the observational data can later be used to complete the research data discussion. Interviews were conducted with various parties related to maintenance management and repair of workshop equipment. The researchers used data collection techniques with interviews to obtain information about more in-depth matters about maintenance management and repair of workshop equipment for machining practices and phenomena that occur. This interview is intended for the head of expertise competency or the head of the machining engineering workshop.

The questionnaire was developed based on research variables namely management of maintenance and repair of machining workshop equipment which includes: planning, actuating, and controlling. The questionnaire statement was compiled and developed based on indicators on the research variables with four choices of answers provided with each answer given a weighting of 4 points ( 1 = not good, 2 = deficient, 3 = good, 4 = very good) where the respondent just gave a checklist on the questionnaire sheet. Data is presented with tables, graphs, and calculations of the mean results. The mean results are interpreted to determine the quality of each indicator of the question being measured. The following is an interpretation of the questionnaire scores in this study: 
Table 2. Interpretation of Questionnaire Scores

\begin{tabular}{|c|ccc|}
\hline Alternative Answers & \multicolumn{3}{|c|}{ Mean } \\
\hline Very Good & 3,26 & - & 4,00 \\
Good & 2,51 & - & 3,25 \\
Deficient & 1,76 & - & 2,50 \\
Not Good & 1,00 & - & 1,75 \\
\hline
\end{tabular}

Data from observations were analyzed descriptively which contained the completeness of machine maintenance equipment and the area supporting the machining engineering workshop. The results of observations serve as a complement to research data so that it can strengthen research results. Interview results were analyzed descriptively to complement the research data. Interview data are used in the discussion of research results to further strengthen and deepen research data obtained through questionnaires.

\section{Results and Discussion}

Industry is one of the links of the economic system because it produces and distributes products (goods or services). Production system is a collection of sub-systems that interact with one another in order to transform production inputs into production outputs that have more value/sale. Therefore, to produce good quality outputs, of course, supported by production activities in the form of maintenance and repair of well-managed machine tools. This study provides an overview of the management of maintenance and repair of workshop equipment in the industry with the management of maintenance and repair of workshop equipment that has been carried out in Vocational High Schools (VHSs).

The maintenance management and repair of workshop equipment at Industry gives a description of the good category, this is almost comparable to the management of maintenance and repairs to VHSs that are included in either category. The process of managing maintenance and repairing workshop equipment consists of three stages, namely planning, actuating and controlling. The results of the survey management of maintenance and repair of workshop equipment at Industry with VHSs Machining Techniques as shown below:

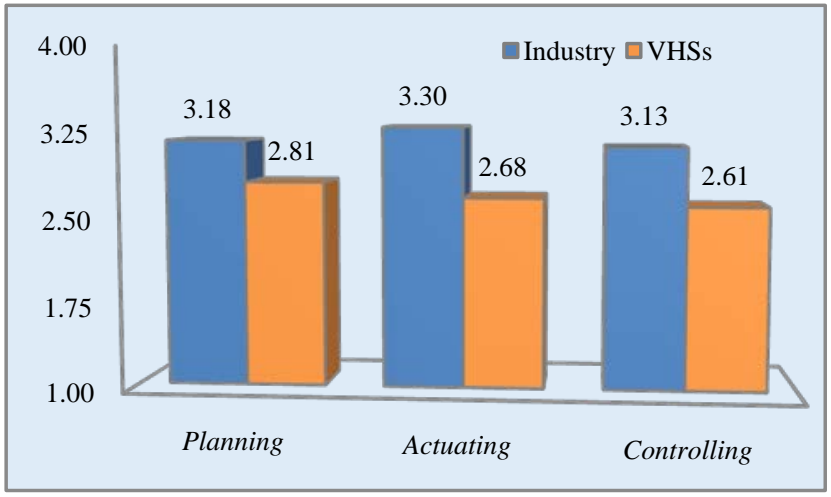

Figure 1. Diagram of survey results for maintenance management and repair of workshop equipment

Figure 1 shows that the management of maintenance and repair of workshop equipment in the industry has a good quality planning with a mean of 3.18 while the VHSs has a good quality planning with a mean of 2.81.The mean obtained both have a difference of 0.37 . However, within the guidelines for interpreting the questionnaire scores the mean number of the two still shows good quality planning. The quality of actuating in the Industry has a mean of 3.30 which means it has very good quality, actuating in VHSs has a mean of 2.68 which means it has good quality. The quality of controlling in the Industry shows a mean of 3.13 while the VHSs shows a mean of 2.61 which means that both of them have good quality in controlling managing the maintenance and repair of workshop equipment.

The industry gives a good picture, this provides a comparison of management in VHSs which are also of good quality, but there are several indicators of maintenance and repair management in VHSs that are included in the deficient category compared to Industry. Therefore, VHSs must improve maintenance management and repair workshop equipment to be better. The following details the discussion of each indicator from the management of maintenance and repair of workshop equipment in the industry with VHSs.

\subsection{Planning for Maintenance Management and Repair of Machining Workshop Equipment}

Planning for maintenance management and repair of workshop equipment is reviewed from four indicators, namely: Planning for maintenance mechanisms, budget planning, schedule planning, and planning methods. Survey results from maintenance management and improvement planning can be seen in the following figure:

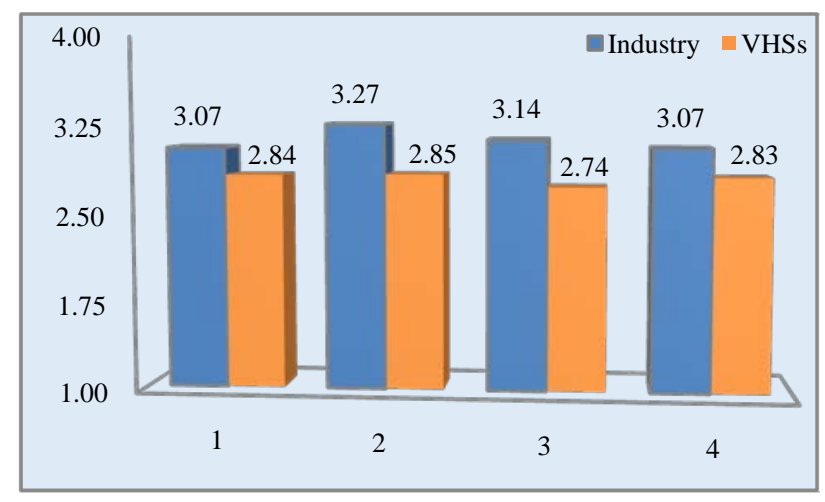

Figure 2. Diagram of survey results for planning maintenance management and repair of workshop equipment

Figure 2 shows that the planning of maintenance and repair of workshop equipment in the industry in terms of planning mechanism has good quality with a mean of 3.07 while at VHSs with a mean of 2.84 which means to have good quality.Budget planning in the industry has a very good quality with a mean of 3.27 while the VHSs has good quality with a mean of 2.84. Indicator of schedule planning in Industry and VHSs has good quality with mean 3.14 and 2.74.The last indicator is planning the method of maintenance, the industry and VHSs have the same quality with the mean of 3.07 and 2.83.

Management of maintenance and repair of workshop equipment in industry based on the determination of 
management planning is included in good categories. Therefore, management planning in Industry provides a better picture or portrait of planning for maintenance management and repair of workshop equipment at VHSs.

Based on the results of interviews on the indicators of mechanism planning, the Industry in planning the maintenance management and repair of workshop equipment is mostly done by the party maintenance but in the implementation of routine maintenance is carried out by the user.The industry in planning maintenance activities always looks at the $5 \mathrm{R}+\mathrm{S}$ culture that must be fulfilled namely: Ringkas, Rapi, Resik, Rawat, Rajin dan Safety(in Indonesian). Industrial management planning uses a product application system (SAP in Indonesia) in the form of a purchase order (PO) to propose products or equipment needed by a machine. This planning process is carried out from the management which is assisted by the user of the machine to find out what the needs that need to be met.

The results of interviews conducted at VHSs showed that the planning of maintenance management and repair of workshop equipment was carried out by the head of the workshop and the head of the department using a written form that was assisted by input from technicians. The form is corrected first by the head of the department before being submitted to the school.

Industry and VHSs, both plan daily, weekly, monthly and yearly maintenance. Annual maintenance is carried out due to a breakdown in the engine. Planned maintenance and repair of workshop equipment at vocational schools have good quality when looking at the planning picture in the industry. This should be maintained and improved by the VHSs so that the planning that has been made can be carried out properly.

\subsection{Actuating for Maintenance Management and Repair of Machining Workshop Equipment}

Actuating in the management of maintenance and repair of workshop equipment consists of seven indicators, namely: suitability of planning and implementation; Equipment management and storage, preventive maintenance; corrective maintenance; emergency maintenance; maintenance personnel in the implementation and reporting/maintenance of machine data. The survey results from the implementation of maintenance and repair management can be seen in the following figure.
Figure 3 shows that the implementation of maintenance and repair of workshop equipment in the industry in terms of the suitability of planning and actuating has a very good quality with a mean of 3.29 while the VHSs has deficient quality with a mean of 2.41. The indicator of the regulation and storage of equipment in the industry has a very good quality with a mean of 3.37 while the VHSs has good quality with a mean of 2.64. Indicators of preventive maintenance activities in the industry and VHSs have the same good quality with a mean of 3.16 and 2.87 . Indicators corrective maintenance activities in the industry and VHSs have the same good quality with a mean of 3.21 and 2.73. Indicators of emergency maintenance activities in the industry have a very good quality with a mean of 3.29 while the VHSs has good quality with a mean of 2.87 . Indicators of care personnel in actuating that exist in the industry have very good quality with a mean of 3.29 while those in VHSs have good quality with a mean of 2.7. The last indicator is the report/engine maintenance data, the industry has a very good quality with a mean of 3.51 while the VHSs has a poor quality with a mean of 2.46.

Based on the results of interviews from the industry in actuating the maintenance management and repair of workshop equipment, carried out by all parties involved in the management of maintenance and repair. All actuating in the industry is controlled by the SAP program which provides all information about maintenance and repairs. Preventive maintenance activities in the industry are carried out by users of each machine, while weekly to annual maintenance is carried out by the maintenance officer by making a report on the maintenance that has been carried out.

The results of the interview at the VHSs in actuating the management of maintenance and repair of workshop equipment were carried out by students, technicians, workshop heads and productive teachers of machining techniques. Actuating management at VHSs often encounters obstacles, related to students' awareness of caring for a machine that they use, so that in carrying out routine or daily maintenance is often ignored. Actuating maintenance and repairs at VHSs starting from corrective maintenance activities to emergency maintenance activities, the technicians have carried out maintenance well, but that has not been matched by the importance of making reports of actuating which can later provide information from the history of a machine. Without a report or engine maintenance history, each machine will be difficult to control the maintenance schedule.

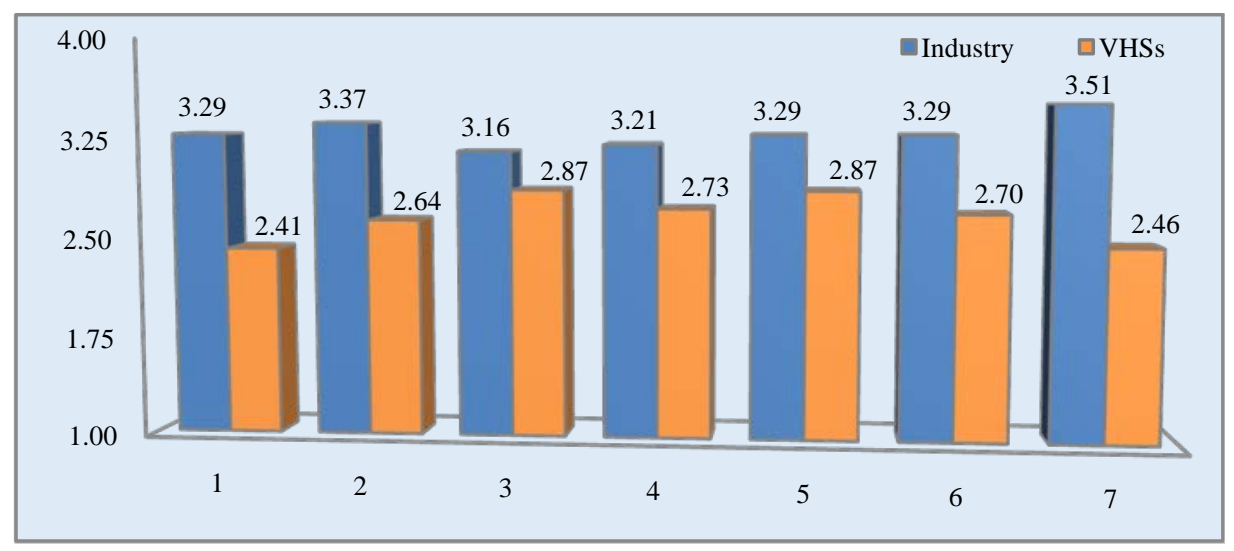

Figure 3. Diagram of actuating survey results for maintenance management and repair of workshop equipment 
Industry and VHSs in actuating maintenance and repair already have good quality, but there are indicators in VHSs that still have poor quality, namely in the reporting process. The industry has a product application system (SAP in Indonesia) that can help with the reporting process, but at VHSs there is still manual recording that is often underestimated in carrying out maintenance and repair management. Management of maintenance and repair of industrial workshop equipment provides a better picture to VHSs from the reporting process.

\subsection{Controlling for Maintenance Management and Repair of Machining Workshop Equipment}

Controlling the maintenance of maintenance and repair of workshop equipment in terms of three indicators, namely: monitoring of maintenance controlling, evaluation of maintenance programs, results of controlling maintenance equipment. The survey results from the maintenance management and repair controlling can be seen in the following figure:

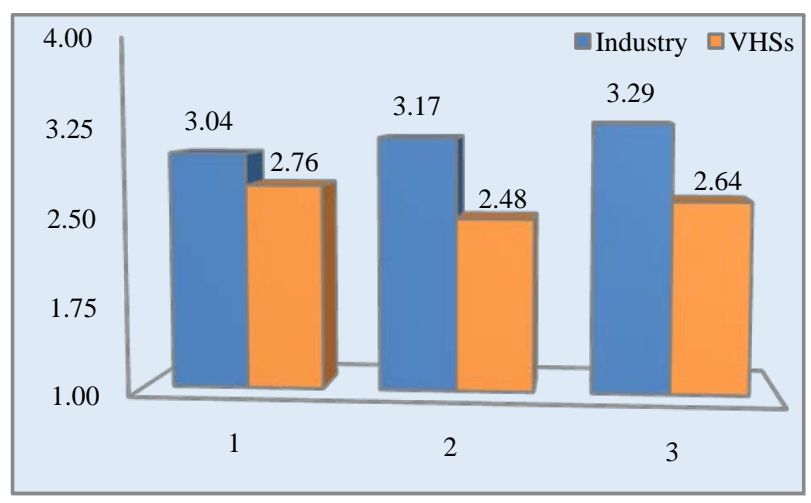

Figure 4. Diagram of controlling survey results for managing maintenance and repairing workshop equipment

Figure 4 shows that controlling maintenance and repair of workshop equipment in the Industry in terms of monitoring controlling maintenance has a good quality with a mean of 3.04 while the VHSs has good quality with a mean of 2.76. Indicators evaluation of treatment programs in the Industry has good quality with a mean of 3.04 while the VHSs has deficient quality with a mean of 2.48. The last indicator is the result of controlling equipment maintenance, Industry has a very good quality with a mean of 3.29 while the VHSs has good quality with a mean of 2.64 .

Based on the results of interviews from the Industry in controlling the management of maintenance and repair of workshop equipment carried out by all parties involved in the management of maintenance and repair. Controlling is done in writing and under control with SAP which is carried out by the user of the machine and maintenance officer that deals directly with machine tools, while other related parties such as management and assets monitor the SAP made by the maintenance parties. Industry in controlling results always evaluates including the implementation, quality of technicians, availability of materials, financial systems and schedule of maintenance activities. Evaluation results are reported and used as a reference for subsequent maintenance and repair activities.
The results of interviews at the VHSs in controlling the management of maintenance and repair of workshop equipment are done by technicians and the head of the workshop conducted in writing and then reported to the head of the department.The monitoring system conducted by the VHSs is included in good quality as illustrated in the controlling monitoring system in the industry. However, the evaluation indicators of VHSs maintenance and repair programs have deficient quality. Evaluation in VHSs only looks at the indicators of actuating activity schedules that are sometimes incompatible with planning without looking at the quality of technicians and the awareness of related parties about the importance of machine maintenance.So, the lack of quality in VHSs evaluation will get problems that are always the same from year to year. A good portrait of the industry can give an idea to VHSs to further improve its management in terms of controlling. So that maintenance and repair activities in the following year can be even better.

\section{Conclusion}

Based on the results of the study it can be concluded as follows: (1) planning in the Industry has good quality with an average of 3.18 while VHSs have good quality with an average of 2.81 ; (2) actuation in Industry has a very good quality with an average of 3.30 while in VHSs it has good quality with an average of 2.68; and (3) controlling the industry has good quality with an average of 3.13 while VHSs have good quality with an average of 2.61 . Maintenance management and repair of workshop equipment in industry-based VHSs has good quality, but it still needs to be improved again with the presence of several indicators of poor quality.

Based on the conclusions of this study, the researcher would like to give advice regarding the management of maintenance and repair of workshop equipment in VHSs as follows: (1) actuating maintenance management and repair of VHSs workshop equipment is further improved, especially related to the suitability of planning with actuating as well as to the reports of engine maintenance data that have deficient quality; (2) controlling the management of maintenance and repair of VHSs equipment needs to be improved related to the evaluation of maintenance programs that have deficient quality. Therefore, by doing this research, VHSs can find out the extent of the management that has been carried out and the Industry can provide an overview and solution to the management of VHSs to be even better.

\section{References}

[1] Istrate, R., Schmitt, M., Apfel, J., dan Ilca, I., "Efficiency of maintenance in steel making industry," International Journal Of Engineering, vol. 9, no. 4, hlm. 91-94, 2011.

[2] Arslankaya S., dan Atay, H., "Maintenance Management and Lean Manufacturing Practices in a Firm Which Produces Dairy Products,” Procedia - Social and Behavioral Sciences, vol. 207, hlm. 214-224, Okt 2015.

[3] Mehmeti, Xh., Mehmeti, B., dan Sejdiu, Rr., “The equipment maintenance management in manufacturing enterprises," IFACPapersOnLine, vol. 51, no. 30, hlm. 800-802, 2018. 
[4] Komonen, K., "A cost model of industrial maintenance for profitability analysis and benchmarking," International Journal of Production Economics, vol. 79, no. 1, hlm. 15-31, Sep 2002.

[5] Pemerintah Indonesia, Penjelasan Undang-Undang No. 20 Tahun 2003 tentang Sistem Pendidikan Nasional, Tambahan Lembaran Negara RI Tahun 2003 No. 4301, Sekretariat Negara, Jakarta, 2003.

[6] Rani, N. A. A., Baharum, M. R., Akbar, A. R. N., dan Nawawi, A. H., "Perception of Maintenance Management Strategy on Healthcare Facilities," Procedia - Social and Behavioral Sciences, vol. 170, hlm. 272-281, Jan 2015.

[7] Slaichova, E., dan Marsikova, K., "The Effect of Implementing a Maintenance Information System on the Efficiency of Production Facilities,” JOC, vol. 5, no. 3, hlm. 60-75, Sep 2013.

[8] Purwanto, P., dan Sukardi, T., "Pengelolaan Bengkel Praktik Smk Teknik Pemesinan Di Kabupaten Purworejo,” Jurnal Pendidikan Teknologi dan Kejuruan, vol. 22, no. 3, hlm. 291, Nov 2015.

[9] Badan Standar Nasional Pendidikan (BSNP),Standar Nasional Pendidikan Perlu Mendapat Perhatian dalam RPJMN 2020-2024, Standar Nasional Pendidikan, Mar 23, 2018. Retrieved from: http://bsnp-indonesia.org/2018/03/23/standar-nasional-pendidikanperlu-mendapat-perhatian-dalam-rpjmn-2020-2024.

[10] Depdiknas, Peraturan Menteri Pendidikan Nasional Republik Indonesia Nomor 40, Tahun 2008, tentang Standar Sarana dan Prasarana Sekolah Menengah Kejuruan/Madrasah Aliyah Kejuruan (SMK / MAK), Sekretariat Negara, Jakarta, 2008. Retrieved from: http://bsnp-indonesia.org/id/wpcontent/uploads/sarana/Permen_40_Th-2008.zip.

[11] Sitinjak, Jefri, Manajemen Perawatan, PPPTK, Medan, 2006.

[12] Franciosi, C., Lambiase, A., dan Miranda, S., "Sustainable Maintenance: a Periodic Preventive Maintenance Model with Sustainable Spare Parts Management," IFAC-PapersOnLine, vol. 50, no. 1, hlm. 13692-13697, Jul 2017.

[13] Sukardi, T., "Pemberdayaan Perawatan dan Perbaikan Fasilitas Praktik Berbasis Siswa di SMK Rumpun Teknologi,” vol. 11, hlm. $1-11$.
[14] Sofjan, Assauri, Manajemen Produksi dan Operasi edisi revisi, Lembaga Penerbit FEUI, Jakarta, 2004, 96. [E-book] Available: https://scholar.google.co.id/scholar?hl=id\&as_sdt=0,5\&cluster=30 58677169674253812.

[15] Amiri, S., Honarvar, M., dan sadegheih, A., "Providing an integrated Model for Planning and Scheduling Energy Hubs and preventive maintenance,” Energy, vol. 163, hlm. 1093-1114, Nov 2018.

[16] Tunčikienè, Ž., dan Grigas, V., "Vadybos funkciju sv arba orlaiviu techninès priežiūros kokybei," Science-Future of Lithuania, vol. 9, no. 2, hlm. 162-170, Jun 2017.

[17] Kent, M. D., Costello, O., Phelan, S., dan Petrov, K., "Cost Oriented Maintenance Management Systems for Manufacturing Processes.,” IFAC-PapersOnLine, vol. 51, no. 30, hlm. 48-53, 2018.

[18] Handoko, T. Hani., Pengantar Manajemen, BPFE, Yogyakarta, 1995. Available: https://scholar.google.co.id/scholar?hl=id\&as_sdt=0,5\&cluster=40 23857622776239582.

[19] Firmansyah, M. A., dan Mahardhika, B. W., Pengantar manajemen, Grup Penerbitan CV BUDI UTAMA, Yogyakarta, April 2018, 39-40.

[20] Kristiawan, M., Safitri, D., dan Lestari, R., Manajemen pendidikan, Grup Penerbitan CV BUDI UTAMA, Yogyakarta, Februari 2017, 28-29.

[21] Arsana, I.P.J., Manajemen pengadaan barang dan jasa pemerintahan, Grup Penerbitan CV BUDI UTAMA, Yogyakarta, November 2016, 17-18.

[22] Herujito, Y.M., Dasar-dasar manajemen, Gramedia Widiasarana Indonesia PT Grasindo, Jakarta, 2006, 28-30.

[23] Hasibuan, Malayu, S.P., dan Haji, Manajemen: Dasar, Pengertian, dan Masalah,Bumi Aksara, Jakarta,2003, 244-245.

[24] Sugiyono, Metode Penelitian Kuantitatif Kualitatif dan R \& D, Alfabeta, Bandung, 2014.

[25] Yamane, Taro, Statistics: An Introductory Analysis, 2nd Edition, Harper and Row, New York, 1967.

(C) The Author(s) 2019. This article is an open access article distributed under the terms and conditions of the Creative Commons Attribution (CC BY) license (http://creativecommons.org/licenses/by/4.0/). 